\title{
SAME-SEX MARRIAGES In Canadian Private InTERnATIONAL LAW
}

\author{
JAN JAKOB BORNHEIM*
}

In 2012, the Canadian federal government took a position in court that same-sex couples married in Canada were not legally married if the law of their domicile did not recognize such marriages. As a reaction to the subsequent media reports and political debate, the government introduced Bill C-32 to modify the Civil Marriages Act. This article analyzes the current treatment of same-sex marriages by foreigndomiciled spouses in Canadian private international law, criticizes the changes to the Civil Marriage Act, and replies to a recent academic commentary on the issue.
En 2012, le gouvernement fédéral canadien prit position en cour que les couples de même sexe mariés au Canada n'étaient pas légalement mariés si la loi de leur lieu de domicile ne reconnaissait pas ces mariages. En guise de réaction aux rapports des médias et au débat politique qui suivirent, le gouvernement présenta le projet de loi C-32 modifiant la Loi sur le mariage civil. L'auteur de cet article analyse la manière dont les mariages de même sexe sont traités par les conjoints vivants à l'étranger dans le cadre du droit international privé canadien, il critique les changements à la Loi sur le mariage civil et répond à un récent commentaire doctrinal sur la question.

\section{TABLE OF ConTENTS}

I. INTRODUCTION $\ldots \ldots \ldots \ldots \ldots \ldots \ldots \ldots \ldots \ldots \ldots$

II. SAME-SeX MARRIAGE BetWeEn SPOUSES

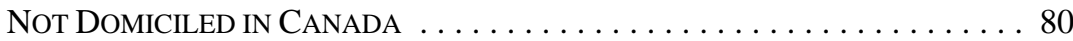

A. EfFEctS of MARRIAGE $\ldots \ldots \ldots \ldots \ldots \ldots \ldots \ldots \ldots \ldots \ldots$

B. The InCIDENTAL QUESTION $\ldots \ldots \ldots \ldots \ldots \ldots \ldots \ldots \ldots \ldots$

C. Determining the Applicable Law: The Domicile Rule . . . . . . 82

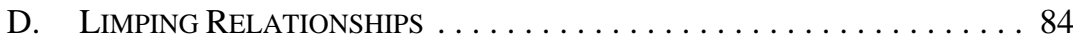

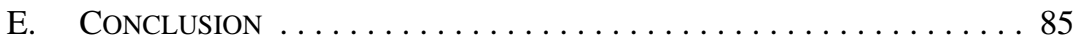

III. PUBLIC POLICY EXCEPTION $\ldots \ldots \ldots \ldots \ldots \ldots \ldots \ldots \ldots \ldots \ldots \ldots \ldots$

A. INTERNATIONAL COMITY

AND the Public Policy EXCEPTION DoctRine $\ldots \ldots \ldots \ldots \ldots$. . . . 85

B. SAME-SEX COUPLES, DivORCE, AND

THE PUBLIC POLICY EXCEPTION $\ldots \ldots \ldots \ldots \ldots \ldots \ldots$

C. InTERnAtionALly MANDATORY Rules $\ldots \ldots \ldots \ldots \ldots \ldots \ldots \ldots$

D. EX-Post LEgITIMIZATION OF A CANAdian MARRiage

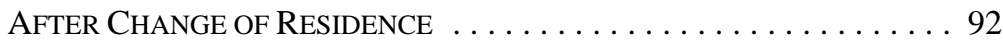

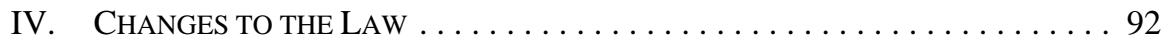

A. Changing the JuRisdiction Rule in the DivorCE ACT . . . . . . . 92

B. Changing Private International LaW . . . . . . . . . . . . . . 94

C. NO CONSTITUTIONAL IMPEDIMENT TO AN EXTRATERRITORIAL

APPLICATION OF CANADIAN MARRIAGE LAWS . . . . . . . 95

V. Alternative Proposal . . . . . . . . . . . . . . . . 95

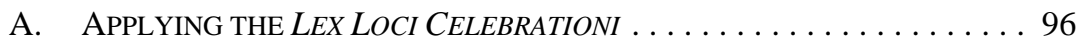

Mag iur, LLM, Assessor, Dr iur candidate at the University of Cologne, Germany. I would like to thank the peer reviewers for their valuable feedback and the excellent editors of the Alberta Law Review for their assistance. Errors and omissions are my own. 


\section{B. RePlacing Domicile With Habitual Residence . . . . . . . . 97 \\ C. Constitutional POWER for CHANGE . . . . . . . . . . . . . . . 98}

VI. CONCLUSION ............................... 100

\section{INTRODUCTION}

The purpose of this article is threefold. First, it seeks to analyze the current treatment of same-sex marriages by foreign-domiciled spouses in Canadian private international law. Second, it criticizes the government's reaction and change of the Civil Marriage Act ${ }^{1}$ and the Divorce Act ${ }^{2}$ (Bill C-32 $2^{3}$ ) as insufficient on the one hand and unprincipled and overreaching on the other hand. Third, it serves as a reply to recent contributions by Jean Gabriel Castel and Matthew Castel $^{4}$ and Brenda Cossman ${ }^{5}$ on this issue.

In 2012, news broke that the Canadian federal government had taken the position in court that same-sex couples married in Canada were not legally married if the law of their domicile did not recognize such marriages. ${ }^{6}$ The case involved a couple that got married in Canada. One spouse was resident in Florida, the other in the United Kingdom. In Florida, no same-sex union is recognized, whereas in the UK at that time, same-sex couples had the option of entering a registered partnership. ${ }^{7}$ In their motion before the Ontario Superior Court of Justice, the spouses requested that they be granted parens patriae jurisdiction for a divorce even though they did not meet the one-year residency requirement in section 3(1) of the Divorce Act. ${ }^{8}$ The responding lawyer on behalf of the Attorney General of Canada responded that in the view of the Attorney General of Canada, the applicants were not legally married in Canada because the applicable law did not recognize their capacity to marry each other. Apparently, the case never culminated in a judgment, and, currently, litigation is set to resume in the next few weeks. For this, it might be worthwhile to note that the provisions of Bill C-32 apply retroactively. ${ }^{9}$

In reaction to the media reports and ensuing political debate, the government introduced Bill C-32 in Parliament. After being stalled for over a year, the bill was rushed through

\section{SC 2005, с 33 [CMA].}

RSC 1985, c 3.

An Act to amend the Civil Marriage Act, 1st Sess, 41st Parl, 2012 (assented to 26 June 2013), SC 2013, c 30 .

$4 \quad$ Jean Gabriel Castel \& Matthew E Castel, "The Marriage and Divorce in Canada of Non-Domiciled and Non-Resident Persons" (2012) 31:3 Can Fam LQ 297.

$5 \quad$ Brenda Cossman, “Exporting Same-Sex Marriage, Importing Same-Sex Divorce - (Or How Canada’s Marriage and Divorce Laws Unleashed a Private International Law Nightmare and What to Do About It)" (2013) 32:1 Can Fam LQ 1.

6 Applicant Submissions, (1 September 2005) FS-11-367893 (Ont Sup Ct J); Respondent Submissions, (15 June 2007) FS-11-367893 (Ont Sup Ct J). Kirk Makin, “Despite legal about-face, Harper has 'no intention' of reopening gay marriage” The Globe and Mail (12 January 2012), online: The Globe and Mail <http://www.theglobeandmail.com/news/politics/despite-legal-about-face-harper-has-no-intentionof-reopening-same-sex-marriage/ article1358276/>; Janyce McGregor, "Same-sex divorce options explored by Harper government: Federal government intervening in cases about validity of same-sex marriages," CBC News (12 January 2012), online: CBC News <http://www.cbc.ca/news/politics/story/ 2012/01/12/pol-harper-same-sex-marriage.html>. Civil Partnership Act 2004 (UK), c 33. At the time of publication, Bill 34, Marriage (Same Sex Couples) Bill, 2012-13 to 2013-14 Sess had become the Marriage (Same Sex Couples) Act 2013 (UK), c 30. 
Parliament with no debate, ${ }^{10}$ and royal assent was given to Bill C-32 on 26 June 2013. Bill C-32 modifies the CMA. The latter now contains two new key provisions: section 5(1) deals with the validity of same-sex marriages of foreign-domiciled spouses, and section $7(1)$ (which has not yet entered into force) deals with their divorce.

The key change is in section 5(1) of the CMA which now reads as follows:

A marriage that is performed in Canada and that would be valid in Canada if the spouses were domiciled in Canada is valid for the purposes of Canadian law even though either or both of the spouses do not, at the time of the marriage, have the capacity to enter into it under the law of their respective state of domicile. ${ }^{11}$

The key provision in section 7(1) of the CMA is section (1)(c) which will give a Canadian court jurisdiction to grant a divorce if "each of the spouses is residing — and for at least one year immediately before the application is made, has resided — in a state where a divorce cannot be granted because that state does not recognize the validity of the marriage."12

In other words, section 5 of the CMA deals with the recognition of, and the law applicable to, a marriage performed in Canada between foreign-domiciled spouses, while section 7 deals with jurisdiction for divorce proceedings.

While Bill C-32 was still before Parliament, it was already the subject of analysis by Castel and Castel. They identified several shortcomings in the bill, foremost that in the event of a divorce of a same-sex couple whose marriage is not recognized in the jurisdiction of their domicile, the Canadian court will not be able to grant corollary relief, and, even if it were, the order would most likely be unenforceable in the ex-spouses' state of domicile. ${ }^{13}$ The same problem will arise regarding the division of property. ${ }^{14}$

This article differs from Castel and Castel's approach in that it focuses more strongly on the comparative principles of private international law. One question that needs to be addressed first is if a change of the current law was even necessary and, if yes, why? This requires a look at the general conflict-of-laws rules for marriage and divorce before the passage of Bill C-32, and at how the Ontario court reached its result (see Part II, below). The article examines, in particular, whether a case can be made that Canadian public policy requires one to disregard any foreign system of laws that does not recognize same-sex marriage (Part III, below). ${ }^{15}$ Then, the options for changing the current law are examined; constitutional aspects of conflict-of-laws legislation are taken into account (see Part IV, below). Finally, the article makes a case for an alternative proposal (see Part V, below).

10

See Meagan Fitzpatrick, "Same-sex divorce available soon to non-residents in Canada: Civil marriage bill introduced in early 2012 finally passed in Commons deal last week,” CBC News (26 June 2013), online: CBC News <http://www.cbc.ca/news/politics/story/2013/06/26/pol-same-sex-divorce-bill.html>. Supra note 1, s 5(1), as amended by SC 2013, c 30, s 3.

Ibid, s 7(1)(c), as amended by SC 2013, c 30, s 4.

Castel \& Castel, supra note 4 at 303-304.

Ibid at 304.

This is hinted at in ibid at 300 where the authors imply that any foreign law that does not recognize a same-sex marriage should be inapplicable in a Canadian court. 
The article agrees with Castel and Castel's analysis that Bill C-32 is bad legislation. It argues that the changes enacted by Parliament go both too far and not far enough. They go too far because they apply Canadian law even though there is minimal territorial connection with Canada, thus furthering the problem of limping relationships. ${ }^{16}$ They do not go far enough because they do not replace the connecting factor of domicile with the more suitable concept of habitual or ordinary residence, and because they do not properly consider the incidents of marriage. Unlike Castel and Castel, there is no focus on identifying the shortcomings of the legislation, which they have achieved comprehensively. Rather, this article proposes another solution.

\section{SAME-SeX MARriage BetweEn SPOUSES NOT DOMICILED IN CANADA}

This section looks at the conflict-of-laws as it stood before the enactment of Bill C-32 regime regarding marriage in Canada. It examines why, when, and to what extent a Canadian court applies the laws of another jurisdiction regarding marriage.

\section{A. EFFECTS OF MARRIAGE}

If we consider marriage from a legal perspective, we must separate the legal meaning of a marriage from the emotional, psychological, and social value attached to it. The main reason a same-sex couple would travel to Canada to marry rather than perform a ceremony at their home domicile — where same-sex marriage is illegal — is the hope that the legal status of same-sex marriage in Canada creates legal effects. The expectation that a marriage taking place on Canadian soil will result in actual legal effects might increase the emotional, psychological, and social value attached to a marriage ceremony taking place in Canada as opposed to one performed in the spouses' home jurisdiction.

Marriage has two legal effects: a status change and incidental rights. ${ }^{17}$ Status is

a special condition of a continuous and institutional nature, differing from the legal position of the normal person, which is conferred by law and not purely by the act of the parties, whenever a person occupies a position of which the creation, continuance or relinquishment and the incidents are a matter of sufficient social or public concern. ${ }^{18}$

The incidents of marriage, on the other hand, are the legal consequences of the status change. For instance, in general, each spouse has a claim against their partner for support. There are additional incidents of marriage, both in private law and public law (for example in tax law). One further notable incident of marriage, at least in Canada, is the inability to enter a second marriage while the first marriage subsists. ${ }^{19}$ 


\section{B. THE INCIDENTAL QUESTION}

An analysis of the problem of divorces of same-sex couples domiciled outside Canada requires us to grasp why foreign law is applied in these cases at all; after all, it may seem counterintuitive that it should be impossible to divorce a marriage celebrated in Canada. Yet this is a result of the applicability of foreign law, which in turn results from the rules of private international law.

Legal rules governing a certain legal relationship may contain conditions which cannot be answered by reference to facts but must be answered by another legal analysis. For instance, the question as to which rights derive from a contract require one to look at whether a contract was concluded, which in turn requires, inter alia, that both parties have the capacity to contract. Legal capacity itself is not merely a factual question but can only be determined by looking at the rules that state whether a person has capacity or not. This determination is then done by reference to fact, or may require one to do yet another legal analysis. In private international law, the initial legal question — in our example, rights deriving from contract - may be governed by different rules than the further questions that derive from it. This is referred to as the "incidental question." ${ }^{20}$ The reason for this split of applicable rules lies in the structure of private international law, where a connecting factor is used to localize the legal question. If the connecting factor for the initial question and for the incidental question differ, different laws will be applied to the initial and the incidental question.

Incidental questions do not only arise in our contract example. If a person has married once, and now wants to marry again, her capacity to marry depends on the validity of the divorce of the first marriage; the validity of the divorce is an incidental question to the initial question "validity of the second marriage." ${ }^{21}$ Furthermore, the status of being married is a requirement for divorce. If at the time of the marriage, one of the spouses lacked the capacity to get married, the marriage is void and a divorce is impossible. ${ }^{22}$

This is the exact situation in which the aforementioned couple found itself: the Attorney General opposed the granting of a divorce because they were, in his view, not married in the first place. He essentially argued that the status effect of marriage never occurred. The next subsection will elaborate on the Attorney General's short submission in the case and analyze the legal situation before the enactment of Bill C-32. University Press, 2008) at 51-54; Sir Lawrence Collins, Dicey, Morris and Collins on the Conflict of Laws, 14th ed (London: Sweet \& Maxwell, 2006) vol 1 at paras 2-046-2-049.

21 See Schwebel v Ungar, [1965] SCR 148. See also Fawcett \& Carruthers ibid at 52-54; K Lysyk, "Conflict of Laws - Status - Capacity to Marry - Recognition of Prior Foreign Divorce - The Incidental Question,” Case Comment on Schwebel v Ungar 43:2 Can Bar Rev 363; PRH Webb, "Bigamy and Capacity to Marry: Based on Schwebel v. Ungar (Or Schwebel)" (1965) 14:2 ICLQ 659. 


\section{Determining the Applicable LAW: The Domicile Rule}

Having concluded that being legally married is a requirement for divorce, we now look at how to determine the marital status of a person. A potential approach is to always apply the law of the place where the marriage was celebrated, or to at least always assume that a marriage celebrated in Canada is legally valid. A news report by the CBC strongly implied that this principle is accepted in the Canadian legal community and that it derives from the decision in Connolly v. Woolrich. ${ }^{23}$ However, that 1867 case only dealt with the question as to which law determined the formal validity of a marriage celebrated in the North West Company territory. The Court held that since neither French, nor English, nor Canon law had at that point ever been introduced in the North West Territories, a marriage celebrated there did not need to conform to the legal formalities of these laws. But apart from formal validity, the validity of marriage has another aspect: essential validity. To inquire about "formal validity" means asking whether the marriage was entered into according to the correct procedure. It is generally governed by the lex loci celebrationis. ${ }^{24}$ Further, on the formal aspect of marriage, we should notice that Canadian jurisdictions generally allow people to have a formally valid marriage without checking whether they have the capacity to marry under the applicable law. "Essential validity," on the other hand, asks whether the parties had the legal capacity to enter the marriage in question. How then does one determine the law applicable on essential validity? The following two sections consider this problem.

\section{COMMON LAW}

As a general rule, in the common law provinces, the essential validity of marriage depends on the capacity of each spouse to enter the marriage. ${ }^{26}$ Traditionally in Canada and England, the connecting factor ${ }^{27}$ "domicile" has been used in order to determine the law applicable to the essential validity of marriage. This law of the domicile is called the lex domicilii. This differs from the traditional approach in at least some jurisdictions in the United States, where the general rule is that the entire validity — formal and substantive — of the marriage is governed by the law of the place of the wedding, ${ }^{28}$ the lex loci celebrationis. ${ }^{29}$

Domicile is a legal concept, not merely a fact. Every person has a domicile of origin, fixed at birth, which can be replaced by a domicile of choice. ${ }^{30}$ Taking up a domicile of choice requires two elements be met: the establishment of a new residence in another jurisdiction, and the intention to remain there. ${ }^{31}$ Both elements must be connected in such a way that the

(1867), 11 LC 197 (QC Sup Ct) [Connolly]; Laura Payton, “Conservatives to change civil marriage law: Tories blames Liberals for gap in law; expert says there’s no gap,” CBC News (13 January 2012), online: CBC News <http://www.cbc.ca/news/politics/story/2012/01/13/pol-same-sex-marriage-nicholson. html>.

See Keddie v Currie (1991), 85 DLR (4th) 342 (BCCA); Connolly, ibid.

See e.g. Marriage Act, RSO 1990, c M.3.

Brook $v$ Brook (1861), 9 HLC 193 (Eng).

Regarding the term "connecting factor" see generally Collins, supra note 20 at paras 1-078-1-088. See Bloch v Bloch, 473 F (2d) 1067 (3d Cir 1973) (US).

For recent developments, see Linda J Silberman, "Rethinking Rules of Conflict of Laws in Marriage and Divorce in the United States: What Can We Learn from Europe?” (2008) 82 Tul L Rev 1999 at 2001. See Janet Walker, Castel \& Walker: Canadian Conflict of Laws, 6th ed (Markham: LexisNexis Canada, 2005), ch 4 at 3.

Magurn v Magurn (1883), 3 OR 570 (Ont H Ct J) at 579-80, aff'd (1885), 11 OAR 178; Adams v Adams (1909), 14 BCR 301 (SC) at 304; Fairchild v McGillivray (1911), 4 Sask LR 237 (SC) at 239; Bell v Kennedy (1868), LR 1 Sc \& Div 307 (HL (Scot)). 
intention is present at the time the residency exists. ${ }^{32}$ It is possible to abandon the domicile of choice, in which case one reverts to the domicile of origin. ${ }^{33}$

The domicile approach is not without criticism. First, it is argued that the aforementioned "doctrine of reverter" yields unwanted results, re-applying the law of a long abandoned domicile of origin. ${ }^{34}$ Second, because of the subjective element of intent, proving a change of domicile is onerous. ${ }^{35}$ It should further be noted that in Canada, the rule seems to be that the law of domicile is in fact the law not of the present domicile of each spouse, but the intended common domicile of both spouses. ${ }^{36}$ The common intent theory was discussed in Feiner v. Demkowicz, ${ }^{37}$ but in that case, the court did not need to decide whether it was good law. While the parties intended to settle in Canada, and their original common domicile was Poland, the court could apply Canadian domicile not by virtue of the intended domicile, but because there was no evidence on the contents of Polish law.

\section{CIVIL LAW}

In Quebec, private international law is codified in the ninth book of the Civil Code of Quebec. ${ }^{38}$ Regarding the essential validity of marriage, article 3088 makes reference to the law governing the personal status of the spouses. According to article 3083, personal status of a person is governed by the law of their "domicile." However, the civil law domicile differs from common law domicile in that it does not require the element of intent as a necessary condition. ${ }^{39}$ As a general rule, in Quebec civil law, domicile is a person's habitual residence. ${ }^{40}$ In many other civil law countries, nationality was traditionally used as the primary connecting factor. ${ }^{41}$

\section{CONCLUSION}

From the facts of the 2012 case, it is clear that the parties had neither common law nor civil law domicile in Canada. Under Canadian conflict-of-laws rules, Canadian law would in principle not be called on to determine the essential validity of their marriage. Rather, it was governed by their domicile, which at that time did not recognize same-sex marriage. This means that they did not have the capacity to marry a same-sex partner.

See e.g. McCormack v McCormack (1920), 15 Alta LR 490, (SC (AD)) [McCormack]; Walcott v Walcott (1915), 23 DLR 261 (NSSC); Crosby v Thomson, [1926] 4 DLR 56 (NBSC (AD)).

Udny v Udny (1869), LR 1 Sc \& Div 441 (HL (Scot)); Barton v Barton, [1940] 3 DLR 211 (Sask CA), aff'g [1940] 2 DLR 465 (Sask KB); Nelson v Nelson (1929), 24 Sask LR 250 (CA); Breen v Breen, [1929] 4 DLR 649 (Man KB), rev’d (1929), [1930] 1 DLR 1006 (Man CA); Nelson v Nelson, cf [1925] 3 DLR 22 (Alta SC) at 27; Jones v Kline, [1938] 4 DLR 391 (Alta SC) at 399-400.

Walker, supra note 30 , ch 4 at 7.

See ibid, ch 4 at 10.

See Canada (Minister of Employment and Immigration) v Narwal, [1990] 2 FC 385 (FCA); Bailey, supra note 17 at 1018. The theory is also advanced in Briggs, supra note 20 at 244; Fawcett \& Carruthers, supra note 20 at $900-901$.

(1973), 2 OR (2d) 121 (H Ct J).

SQ 1991, c 64 [CCQ].

Ibid, art 75; Bonilla c Lefebvre, [1964] BR 102.

Claude Emanuelli, Droit international privé québécois, 2d ed (Montreal: Wilson \& Lafleur, 2006) at para 115.

See Bailey, supra note 17 at 1010, n 17. 


\section{LIMPING RELATIONSHIPS}

Before we consider whether the result of the straight application of the general conflict-oflaws rule should be modified as a matter of principle, we need to consider a private international law phenomenon known as "limping relationships." When recognizing samesex marriages in Canada by foreign-domiciled couples, their marriage should also be recognized in other jurisdictions, particularly the law at the couple's intended joint residence.

Private international law is essentially national law ${ }^{42}$ and differs from jurisdiction to jurisdiction. Therefore, the applicable law may differ from forum to forum. This is a function of nationally diverging private international laws. As a result, a legal relationship may be recognized in one jurisdiction which applies one system of law, but not in another jurisdiction which applies another system of law. Such a non-universal relationship is referred to as a "limping relationship"; while the parties move from one jurisdiction to another, private international law rules mean that the legal relationship limps behind. ${ }^{43}$ Regarding the issue at hand, the difficulty same-sex couples marrying in Canada face is that, in their home jurisdiction, their marriage may not be recognized. This was the exact result of one reported case in Ireland, Zappone v. Revenue Commissioners. ${ }^{44}$

In jurisdictions where a registered partnership is possible, it was suggested that a same-sex marriage could be re-characterized as such a partnership. ${ }^{45}$ In these jurisdictions, it would not necessarily contravene public policy to recognize the effects of a divorce of a same-sex marriage as far as the incidental rights of a once-existing marriage are concerned. It is not unknown in private international family law that while the status change itself is not recognized, incidental rights stemming from the status change are given effects. This is often done when recognizing the incidental rights from a polygamous marriage, and a case can be made that the situation as far as same-sex marriages are concerned is similar. ${ }^{46}$

In fact, if one accepts the proposition that in those jurisdictions, where a legally recognized registered partnership regime exists for same-sex couples, these couples could both marry and be divorced in Canada according to the old rules before the enactment of Bill C-32. Such a marriage will be re-characterized as a registered partnership in the spouses' home jurisdiction. Such a registered partnership in turn constitutes a "marriage" for the purposes of Canadian divorce law. ${ }^{47}$ Provided that a Canadian court has jurisdiction, there is thus no issue in having such a same-sex marriage concluded in Canada, dissolved in Canada. In the initially-mentioned case, this was not possible because Florida does not recognize any type of same-sex union.

$42 \quad$ Emanuelli, supra note 40 at para 20; Walker, supra note 30, ch 1 at 2.

43 See e.g. Patrick Wautelet, "Private International Law Aspects of Same-Sex Marriages and Partnerships in Europe — Divided We Stand?” in Katharina Boele-Woelki \& Angelika Fuchs, eds, Legal Recognition of Same-Sex Relationships in Europe (Cambridge: Intersentia, 2012) 143 at 148, 158.

44 [2006] IEHC 404, [2008] 2 IR 417.

45 See Wautelet, supra note 43 at 165-66; Sandro Wiggerich, "Bis dass der Tod sie scheidet? — Probleme der Scheidung ausländischer gleichgeschlechtlicher Ehen am Beispiel Kanadas” (2012) 2012:14 FamRZ 1116.

46 Meinhard Forkert, Eingetragene Lebenspartnerschaften im deutschen IPR: Art. 17b EGBGB (Tübingen: Mohr Siebeck, 2003) at 84.

$47 \quad$ See the convincing discussion in Hincks $v$ Gallardo, 2013 ONSC 129, 113 OR (3d) 654. 


\section{E. CONCLUSION}

In conclusion, the application of the law of domicile of the spouses to determine the capacity to marry and the essential validity of marriage itself was the law at the time of this 2012 decision by the Ontario Superior Court. However, the lex domicilii rule leads to a problematic situation if the legal system of a spouse's domicile does not recognize a person's capacity to marry a same-sex partner nor provides for other legally recognized same-sex unions for the spouses. In these situations, a straightforward application of the domicile rule either prevents this person from entering a legally valid marriage with a same-sex partner in Canada, or is an obstacle to a recognition of this marriage in Canada. Furthermore, as a result of the methodology of private international law and its use of variable connecting factors, marriages are prone to the phenomenon of limping relationship. If one forum uses domicile, a second forum uses nationality, a third forum uses residence, and a fourth jurisdiction uses the place of the wedding as a connecting factor, these four differ and the laws of the four destination jurisdictions - law of domicile, law of nationality, law of residence, law of place of celebration - are different regarding the permissibility of same-sex unions (outright prohibition, registered partnership, or same-sex marriage), the marriage might be recognized to different degrees in different jurisdictions.

\section{Public Policy Exception}

\section{A. INTERNATIONAL COMITY AND the Public Policy Exception Doctrine}

The Attorney General's stance on the essential validity — or rather invalidity — of samesex marriages between certain foreign-domiciled partners was criticized in the media and by politicians, based on the argument that the rules of private international law should not be placed above the constitution. ${ }^{48}$ In private international law terminology, such an argument is referred to as the "public policy exception." "The principle that a rule of foreign law will not be applied if the outcome of the application of the rule violates the forum's public policy is part of the common law conflict of laws. It also applies in questions of capacity to marry. ${ }^{50}$ Therefore, it is plausible to argue that denying same-sex couples a divorce on the grounds that the law of their domicile does not recognize their marriage is a violation of Canada's public policy, and the law of domicile should not be applied. However, such an argument depends on whether the public policy exception can indeed be raised unconditionally.

\section{COMITY}

Because the public policy exception is an exception to a rule, a decision as to whether it can be successfully raised should depend on what the reasoning behind the rule is in the first

See e.g. “' 'Law of domicile’ should have no veto on the Constitution,” The Globe and Mail (12 January 2012), online: The Globe and Mail <http://www.theglobeandmail.com/commentary/editorials/law-ofdomicile-should-have-no-veto-on-the-constitution/article1358282/>.

49 See Andreas Bucher, Recueil des cours: L'ordre public et le but social des lois en droit international privé, t 239 (Dort: Martinus Nijhoff, 1993) 9. See also Kent Murphy, “The Traditional View of Public Policy and Ordre Public in Private International Law” (1981) 11:3 Ga J Int'l \& Comp L 591.

50 Cheni v Cheni, [1965] P 85 (Probate Division (Eng)) [Cheni]. See Fawcett \& Carruthers, supra note 20 at $908-10$. 
place. Why then do we apply the law of other jurisdictions? Applying the law of another jurisdiction in a Canadian forum is an expression of international "comity," 51 which means extending something to another state in the expectation that the other state will reciprocate. In other words, we apply the laws of other jurisdictions if the case is most closely connected $^{52}$ to that jurisdiction because we expect other jurisdictions to reciprocate this favour. From this it follows that we cannot refuse to apply foreign law merely because it reaches a result that differs from Canadian law. The public policy exception partly negates this comity. Yet commentators in the media have argued that comity has no role to play in deciding whether to apply foreign, discriminatory, family law. ${ }^{53}$ However, comity cannot be easily dismissed as this principle is at the heart of private international law.

The principle of comity can be traced back to the works of early private international law scholars Joseph Story and Friedrich Savigny. ${ }^{54}$ Both scholars were instrumental in the creation of modern private international law, the former in common law, the latter in civil law. Story approvingly cites an earlier work by 17th century Dutch jurist Ulrich Huber, stating that each jurisdiction recognizes the laws of other jurisdictions in the expectation that the same recognition is awarded to its own law. ${ }^{55}$ Savigny stresses that the reason for the application of foreign law is rooted in the presumption of the equality of different legal systems. $^{56}$

Comity, as a guiding principle, is not only found in legal scholarship, but is also accepted by Canadian courts:

\begin{abstract}
"Comity," in the legal sense, is neither a matter of absolute obligation, on the one hand, nor of mere courtesy and good will, upon the other. But it is the recognition which one nation allows within its territory to the legislative, executive or judicial acts of another nation, having due regard both to international duty and convenience, and to the rights of its own citizens or of other persons who are under the protection of its laws. $^{57}$
\end{abstract}

In Tolofson v. Jensen, ${ }^{58}$ Justice LaForest further refined the Canadian view on comity:

The truth is that a system of law built on what a particular court considers to be the expectations of the parties or what it thinks is fair, without engaging in further probing about what it means by this, does not bear the

51 See for a recent view of the comity principle Adrian Briggs, Recueil de cours: The Principle of Comity in Private International Law, 354 (The Hague: Martinus Nijhoff, 2012), 66 at 82 where Briggs writes: "For as will be sought to be shown, the observance of the principle of comity is the essence, the rule, of the common law of private international law."

52 Regarding the "closest connection" underpinning of private international law see Friedrich Carl von Savigny, System des heutigen Römischen Rechts (Berlin: Bei Veit und Comp, 1849) vol 8 at 27-28.

$53 \quad$ Emmett Macfarlane, “Are some marriages more equal than others?: Why federal lawyers are wrong to argue same-sex marriages by non-residents aren’t valid” Maclean's (12 January 2012), online: Maclean's <http://www2.macleans.ca/2012/01/12/are-some-marriages-are-more-equal-than-others/>.

54 Savigny, supra note 52; Joseph Story, Commentaries on the Conflict of Laws: Foreign and Domestic, in Regard to Contracts, Rights and Remedies, and Especially in Regard to Marriages, Divorces, Wills, Successions, and Judgments (Boston: Charles C Little and James Brown, 1846); comparing the two: David MacClean, Recueil de Cours: De Conflictu Legum: Perspectives on Private International Law at the Turn of the Century, t 282 (The Hague: Martinus Nijhoff, 2000) 41 at 59-61.

Story, supra note 54 at paras 39-40.

Savigny, supra note 52 at 26-27.

Hilton v Guyot, 159 US 113 (1895) at 163-64 [Hilton] [emphasis added]; cited with approval in Spencer $v$ The Queen, [1985] 2 SCR 278 at 283.

[1994] 3 SCR 1022. 
hallmarks of a rational system of law.... On the international plane, the relevant underlying reality is the territorial limits of law under the international legal order. The underlying postulate of public international law is that generally each state has jurisdiction to make and apply law within its territorial limit. Absent a breach of some overriding norm, other states as a matter of "comity" will ordinarily respect such actions and are hesitant to interfere with what another state chooses to do within those limits. Moreover, to accommodate the movement of people, wealth and skills across state lines, a byproduct of modern civilization, they will in great measure recognize the determination of legal issues in other states. And to promote the same values, they will open their national forums for the resolution of specific legal disputes arising in other jurisdictions consistent with the interests and internal values of the forum state. These are the realities that must be reflected and accommodated in private international law. ${ }^{59}$

In this passage, Justice LaForest addresses two functions of the principle of comity, the distinction being evidenced by the use of "moreover.” First, one jurisdiction will recognize how a case is resolved within the borders of another jurisdiction. In other words, it will recognize judgments and other judicial acts. Second, because in modern society people move across borders, one jurisdiction will recognize the laws of another jurisdiction if the case has a connection with that other jurisdiction. In essence, comity is thus one of the raisons d'être of private international law. However, comity is neither a connecting factor nor a substantive rule by virtue of which the applicable law itself can be determined. ${ }^{60}$ In the words of the German private international law scholar Gerhard Kegel, the principle of comity can be used to describe the development by which jurisdictions have overcome the archaic pretension that only domestic law should apply as the only possible just and right law. ${ }^{61}$

While Peter Kincaid criticizes the reliance on the comity principle in Tolofson v. Jensen, his criticism is more based on the meaning of comity in public international law. He agrees that Justice LaForest "is right in identifying territorial sovereignty as the relevant underlying reality." ${ }^{62}$ He further acknowledges that parties expect that the law which is most closely connected to the facts at hand applies. ${ }^{63}$ It appears, thus, that he would have no problem accepting comity as a principle in Kegel's sense of the word.

\section{The Public Policy EXCEPTION}

In the definition of comity given by the US Supreme Court quoted earlier, it was noted that comity is not an "absolute obligation." 64 In Tolofson v. Jensen as well, it was stressed that comity has its limit when an "overriding norm" is breached. ${ }^{65}$ This is where the public policy exception comes into play. The public policy exception states that the otherwise applicable law is not applied if the result of its application is a breach of the forum's public

Ibid at 1046-47 [emphasis added].

See Davies $v$ Collins, 2011 NSCA 79, 307 NSR (2d) 288 at para 34.

Gerhard Kegel \& Klaus Schurig, Internationales Privatrecht, 9th ed (München: Beck, 2004) at 6.

Peter Kincaid, “Jensen v. Tolofson and the Revolution in Tort Choice of Law” (1995) 74:4 Can Bar Rev 537 at 542.

Ibid at 546 .

Hilton, supra note 57 at 163-64.

Supra note 58 at 1047. 
policy. However, because it overrides the comity principle at the heart of private international law, the public policy exception should be applied narrowly. ${ }^{66}$

One way of restricting the scope of the exception is a spatial requirement. This spatial element is widely accepted in civil law systems, including Quebec in Canada. In Quebec legal terminology, the public policy exception is referred to as the ordre public exception. ${ }^{67}$ The ordre public exception is codified in article 3081 of the CCQ: "The provisions of the law of a foreign country do not apply if their application would be manifestly inconsistent with public order as understood in international relations.”

In Quebec doctrine, a distinction is made between the "ordre public interne" (or internally mandatory law) and the "ordre public internationale." Not every foreign law that reaches a result different from internally mandatory Quebec law can be said to violate the ordre public internationale; rather, to do so, the foreign law must violate fundamental principles, such as the ones that are enshrined in international treaties. ${ }^{68}$ Based on the necessarily international element of the potential public policy violation, it is suggested that a violation of the ordre public can be assumed more easily if the situation has a stronger connection to Quebec by virtue of some of the facts taking place in Quebec. ${ }^{69}$ This spatial requirement must also be met in other jurisdictions in order for the public policy exception to be applied. ${ }^{70}$

Regarding the spatial element in common law, Briggs suggests that there are two sets of public policy violations: the ones that will always trigger the public policy exception and those that will only trigger it if the case has sufficient connection with the forum. ${ }^{71}$ The requirement of a spatial element in common law is supported by Cheni. ${ }^{72}$ However, it seems that a more fine-grained approach should be taken. Rather than distinguish between fundamental rules requiring no forum connection and rules that require such a connection for the exception to apply, we should use both elements as factors: the stronger the forum connection element, the easier it could be said that the domestic legal rule must be placed over foreign law and vice versa. ${ }^{73}$

Another distinction can be drawn between the negative public policy exception (not applying foreign law because its result violates foral public policy) and the positive public policy exception (applying certain rules of the forum because they are deemed essential to public policy). However, the usefulness of such a distinction is of limited value when trying to give substance to international public policy itself. Rather, they are both "different sides of the same coin," describing the two effects of the public policy exception. ${ }^{74}$

66 "The review of the case law confirms that the public policy exemption is narrow, when considered both in the context of applying foreign law in actions brought in Canadian jurisdictions, as well as in enforcing foreign judgments in Canadian provinces, and therefore, it has rarely been applied" (Society of Lloyd's v Meinzer (2001), 55 OR (3d) 688 (CA) at para 60). See also Tolofson v Jensen, supra note 58. See furthermore Collins, supra note 20 at para 5-003.

See Emanuelli, supra note 40 at paras $464-70$.

Ibid at para 469.

Ibid at para 470 .

Kegel \& Schurig, supra note 61 at 523; Bucher, supra note 49 at 52-56.

Briggs, supra note 20 at 49-51; hinted at in Collins, supra note 20, vol 1, at para 5-003.

Cheni, supra note 50.

Hinted at in Bucher, supra note 49 at 52.

Kegel \& Schurig, supra note 61 at 518. 


\section{B. SAME-SeX COUPles, Divorce, AND The Public Policy EXCEPTion}

We now turn to the implications of the public policy exception doctrine for the case at hand, the divorce of foreign-domiciled same-sex couples in Canada. Applying the public policy exception principle, Martha Bailey reaches the conclusion “that if a party's personal law denies capacity to enter into a same-sex marriage, that incapacity should be ignored on public policy grounds. ${ }^{\text {"75 }}$ For her conclusion, Bailey relies on Sottomayer v. de Barros. ${ }^{76}$ This case dealt with a situation where both parties were domiciled in different jurisdictions, the husband being domiciled in England, and the wife in Portugal. Since each party's capacity to marry was governed by the law of its domicile, and under Portuguese law the wife had no capacity to marry unless she received a dispensation from the Pope, the result would have rendered their marriage void. Instead, the Court decided that, since the marriage was celebrated in England, the marriage was valid. In modern law, the rule has been rephrased to state that if one party is domiciled in England and the wedding was celebrated in England, then English law applies. ${ }^{77}$

Sottomayer is heavily criticized because it displays a "xenophobic" preference for domestic law over foreign law, furthering the problem of limping marriages. ${ }^{78}$ Even if one does not reject Sottomayer on these grounds, it nevertheless also stands for the proposition that at least one of the parties must be domiciled in the forum, which is a rather strong territorial connection.

A same-sex couple who comes to Canada, marries here, and leaves immediately has a very weak territorial connection to Canada. Thus, it follows that in order for the public policy exception to apply, the breach of public policy must be substantial. The recognition of samesex unions in Canada is based on an application of the Charter $;^{79}$ the process was started by a line of cases $^{80}$ at the beginning of this century and culminated in an act of Parliament. ${ }^{81}$

In Halpern v. Canada, the Ontario Court of Appeal framed the question in the following way:

The definition of marriage in Canada, for all of the nation's 136 years, has been based on the classic formulation of Lord Penzance in Hyde v. Hyde and Woodmansee: "I conceive that marriage, as understood in Christendom, may for this purpose be defined as the voluntary union for life of one man and one woman, to the exclusion of all others." The central question in this appeal is whether the exclusion of same-sex couples from this common law definition of marriage breaches [section 2(a) or section 15(1) of the Charter] in a manner that is not justified in a free and democratic society under s. 1 of the Charter. ${ }^{82}$

Supra note 17 at 1018.

(1879), 5 PD 94.

Collins, supra note 20, vol 2, at para 17E-106; Fawcett \& Carruthers, supra note 20 at 905.

For the point at hand see ibid at 905-906.

Canadian Charter of Rights and Freedoms, Part I of the Constitution Act, 1982, being Schedule B to the Canada Act 1982 (UK), 1982, c 11 [Charter].

80 Halpern v Canada (Attorney General) (2003), 65 OR (3d) 161 [Halpern]; Hendricks c Québec (Procureur Général), [2002] RJQ 2506 (CS) [Hendricks].

CMA, supra note 1.

Supra note 80 at para 1 [citation omitted]. 
The Court answered the question in three steps. First, the Court clarified that the definition of "marriage" derives from common law. Second, it concluded that a common law definition of marriage that only includes heterosexual couples to the exclusion of same-sex couples is a different treatment and violates section 15(1) of the Charter. Third, it held that the violation of section 15(1) of the Charter cannot be justified by an application of the Oakes test. ${ }^{83}$ The Oakes test is two-pronged: a pressing and substantial objective and the means chosen to achieve this objective are reasonable and demonstrably justifiable in a free and democratic society. Regarding the first prong, the Court held that the purpose of a purely heterosexual definition of marriage can only be seen in maintaining marriage as an exclusively heterosexual institution, but "a purpose that demeans the dignity of same-sex couples is contrary to the values of a free and democratic society and cannot be considered to be pressing and substantial., ${ }^{84}$

In Quebec, the situation was formally different from the common-law provinces because at that time, article 365 of the CCQ used to specify that a marriage is to be contracted between a man and a woman. In Hendricks, this provision was deemed to be a mere reaffirmation of federal law, because the provincial legislator had no authority to stipulate any substantive conditions for marriage. ${ }^{85}$ Instead, the definition of marriage must be derived from federal law. In federal law, section 5 of the Federal Law-Civil Law Harmonization Act, No. 1 originally required "the free and enlightened consent of a man and a woman to be the spouse of the other." ${ }^{86}$ However, the court held that the prohibition of same-sex marriage touches on the equality provision in section 15(1) of the Charter and is discriminatory ${ }^{87}$ Like the Ontario court, it held that the prohibition of same-sex marriage cannot be reasonably justified. $^{88}$

These are the cases that might give us guidance to the question regarding whether a public-policy exception can be successfully raised to derogate from the domicile rule. Unfortunately, these cases, while stating that prohibiting same-sex marriages violates the Canadian constitution, are not instructive as to whether the principle against discriminating against same-sex couples is so strong that it should be applied even when a case has no territorial connection other than the fact that the marriage was solemnized in Canada.

With regards to marriage and divorce, the spatial element should be required because of the problem of limping relationships. It is essential to remember that the recognition of a same-sex marriage of foreign-domiciled spouses might in fact not change the legal effect of the marriage in the jurisdictions where it matters: the spouses' home jurisdiction.

It might hurt Canada's national pride, but it seems probable that the marriage of the two litigants in the case that brought the matter to the media spotlight had in fact no legal consequence. Denying rights to same-sex couples is certainly a breach of Canadian public policy. Yet it is a breach of Canadian public policy by other jurisdictions. Recognizing the

[1986] 1 SCR 103 [Oakes].

Halpern, supra note 80 at para 119.

Hendricks, supra note 80 at paras 136, 155.

SC 2001, c 4.

Hendricks, supra note 80 at paras 136, 155.

Ibid at para 184. 
marriage of a couple that has no connection to Canada other than the place of marriage does nothing to remedy this public policy breach by other jurisdictions. Furthermore, the pretension that Canada can enable spouses from all over the world to enter a legal marriage in Canada is a dishonest exploitation of these people to further the wedding industry business in Canada. Cossman points out that the situation before Bill C-32 was hypocritical, ${ }^{89}$ but unlike her, I would emphasize that it is hypocritical to give hopeful same-sex partners who are resident and domiciled abroad the impression that they will be able to enter a marriage that has any meaningful legal effect by getting married in Canada. The hopeful spouses are given the impression that once they celebrate a wedding in Canada, they are legally married; in truth, their marriage may not be recognized by their home jurisdiction.

It is not entirely impossible that a foreign jurisdiction might recognize the Canadian divorce even though the marriage that was divorced would not be recognized in that jurisdiction. There is foreign precedent for cases where a jurisdiction has recognized a foreign marriage by its residents even though it was invalid under its domestic law. In the US case of Commonwealth $v$. Lane, ${ }^{90}$ Lane had married again in New Hampshire even though his home domicile, Massachusetts, prevented him from marrying again because he had already been divorced. The Massachusetts court held that it would not give extra-territorial effect to Massachusetts law, and thus his New Hampshire marriage was considered to be legal in Massachusetts, as it was legal in New Hampshire. ${ }^{91}$ However, a same-sex couple which was never recognized to be married by their home jurisdiction does not need a divorce to regain the capacity to marry. The spouses always kept it according to the applicable law. Furthermore, it seems doubtful that a court would have given recognition to a foreign divorce by application of the rule in Lane when it was asked to recognize the foreign divorce for corollary relief.

\section{INTERNATIONALLY MANDATORY RULES}

Apart from the public policy exception, there is another way of circumventing the regular coflict-of-laws rule and instead applying the law of the forum. The public policy exception as discussed above is a negative test, because the law of the other jurisdiction is disregarded if its result conflicts with the public policy of the forum. The reverse test is a positive test. The question asked is whether the law of the forum is so important that it is considered to be "internationally mandatory," meaning the law of the forum will be applied regardless of whether it is rendered applicable by the general private international law rules or not.

In the case of same-sex marriage, this means that Canadian family law regarding the capacity for entering into a same-sex marriage should always be applicable. However, this raises two problems. First, the application of an internationally mandatory rule requires minimal contact between the facts of the case and the forum state. ${ }^{92}$ Second, it is not clear whether internationally mandatory rules can be applied even though the otherwise applicable

113 Mass 458 (Sup Jud Ct 1873) [Lane].

See Thomas H Healy, Recueil des cours: Théorie générale de l'ordre public, t 9 (Paris: Libraire Hachete, 1925) 407 at 487-88.

$R v$ Thomas Equipment Ltd, [1979] 2 SCR 529; see Emanuelli, supra note 40 at para 92. 
law reaches a better result, applying the very standard of the domestic mandatory rules. ${ }^{93} \mathrm{In}$ concreto, if Canadian marriage law is internationally mandatory, it may well always be internationally mandatory, even if otherwise applicable law recognizes same-sex marriage or if the spouses are of a different sex (if the rule is gender-neutral).

\section{Ex-Post Legitimization OF A CANAdian MARRIAGE After Change of RESIDENCE}

While the limping-relationship problem weighs against raising the public policy exception in cases of foreign-domiciled couples who are now seeking a divorce, the same does not hold true for couples who were domiciled in a jurisdiction that discriminates against same-sex couples at the time of marriage, but have later moved to Canada and do or do not seek a divorce. Under a strict application of the lex domicilii principle, these couples would have lacked the capacity to marry at the time of the wedding. But the fact that they have moved to Canada later should constitute sufficient territorial connection with Canada, especially since in that case, the limping relationship effect would not create a problem. Thus, under current law, for these cases the public policy exception should succeed.

\section{Changes to the LAW}

After the news about the position of the federal government in the litigation became public, the federal government quickly announced that the non-recognition of same-sex marriages of foreign-domiciled couples was a "legislative gap" that it intended to fix. ${ }^{94}$ This was the purpose of Bill C-32.

\section{A. Changing the Jurisdiction Rule in the DivorCe ACT}

One potential change is to get rid of the one-year residency requirement in section 3(1) of the Divorce Act. In effect, this is what the amended section 7(1)(c) of the CMA will do.

However, this change will only enable a court to hear the case - it would not yet determine which law is to be applied. Since a valid marriage is a requirement for divorce, ${ }^{95}$ striking the residency requirement will still not allow a Canadian court to divorce a same-sex couple if the applicable law does not recognize their marriage.

It should be noted that certain internationally mandatory rules may not apply unconditionally but only if they reach the most favourable result for the "weaker" party involved. This problem is often discussed in a EU context, because of the problem of the internationally mandatory character of rules transforming EU directives vis-à-vis the law of other member states. See recently Jan Lüttringhaus, Grenzüberschreitender Diskriminierungsschutz: Das internationale Privatrecht der Antidiskriminierung (Tübingen: Mohr Siebeck, 2010) at 253-55. See also Gerfried Fischer, "Das Kollisionsrecht der Verbraucherverträge jenseits von Art. 5 EVÜ” in Festschrift für Bernhard Großfeld zum 65. Geburtstag ed by Ulrich Hübner (Heidelberg: Verlag Recht und Wirtschaft, 1999) 277 at 285-86; Thomas Pfeiffer, "Eingriffsnormen und ihr sachlicher Regelungsgegenstand" in Einheit und Vielfalt des Rechts: Festschrift für Reinhold Geimer zum 65. Geburtstag ed by Rolf A Schütze (München: CH Beck, 2002) 821 at 834-35.

Payton, supra note 23; Kirk Makin, “Ottawa affirms legality of same-sex marriages performed in Canada” The Globe and Mail (13 January 2012), online: The Globe and Mail <http://www.theglobeand mail.com/news/politics/ottawa-affirms-legality-of-same-sex-marriages-performed-incanada/article552478/>. 
Furthermore, such an extension of jurisdiction meets another challenge. In general, a foreign jurisdiction will recognize a divorce granted by a Canadian court only if the Canadian court has jurisdiction according not only to its own rules, but also the rules of the other jurisdiction. ${ }^{96}$

This creates the following problem for a divorced same-sex couple: the status change from being a married couple to being a divorced couple cannot be recognized in the couple's home jurisdiction if that jurisdiction does not recognize same-sex marriages in the first place. This in itself might be a minor problem because, from a practical point of view, a divorced couple can be indifferent to the reason for which they are considered to be not married. However, a divorce does not entail only a status change; it will trigger incidental effects, such as the division of property and spousal support, as well. Another incidental effect, child custody and support, is outside the scope of this article because it is not necessarily governed by the same law as that governing the marriage.

In Canada, the incidental effects of a divorce are dealt with in a corollary relief order. Spousal support is dealt with in the Divorce Act, the division of property is in the provincial legislative realm. But outside Canada, there are jurisdictions in which incidental effects of a divorce are not obtained by a court order, but by operation of law as an automatic result of a divorce order - even though the precise extent of these incidental effects might become the subject of a dispute. A Canadian court that is only concerned with the status question might be ignorant to these automatic incidental effects of a divorce.

This is problematic from the standpoint of the same-sex spouses. If the laws of the spouses' home jurisdiction envisions such automatic incidental effects for a divorce, the spouses might expect the Canadian divorce to yield the same automatic incidental effects. However, the Canadian divorce would most likely not create such effects because when section 7(1)(c) of the CMA gives Canadian courts jurisdiction where they do not have jurisdiction under the rules of the home jurisdiction, the home jurisdiction might refuse to recognize any incidental effects of the divorce as well. Provided the spouses have some property in Canada, they might want to get a corollary relief order from a Canadian court to compensate for that. However, section 8 of the CMA will prevent this. It states: "For greater certainty, the Divorce Act does not apply to a divorce granted under this Act."97

It should be noted that the opposition proposed a bill similar to Bill C-32, Bill C-435, ${ }^{98}$ which included a corollary relief provision. However, the bill's sponsor seems to have ignored the fact that this corollary relief would not have any effect outside Canada. ${ }^{99}$

McCormack, supra note 32; Jones $v$ Kline, supra note 33 at 401.

Supra note 1, as amended by SC 2013, c 30, s 8.

Bill C-435, An Act to amend the Civil Marriage Act (divorce and corollary relief), 1st Sess, 41st Parl, 2012.

$99 \quad$ House of Commons Debates, 41st Parl, 1st Sess, Vol 146 No 141 (15 June 2012) at 9626 (Randall Garrison); Cossman, supra note 5 at 9. 


\section{B. Changing Private International LaW}

These problems with a simple change of jurisdiction rule show that any solution to the problem at hand requires a solution on the level of private international law. Such a change is to be effected by the proposed section 5(1) of the CMA. This section is a special clause for marriage in general, not just for cases when a valid marriage is the incidental question in a divorce proceeding. In effect, it is a codification of a public policy exception. It means that Canadian private international law would render domestic law applicable any time the question of "married or not married" is asked in a Canadian forum, not only when it is asked in a divorce context.

Such a rule is not without precedent. However, looking at the examples, one sees that the special rules for same-sex marriage do not change the otherwise applicable law without conditions. The widest rule can be found in Belgium, where article 46(2) Code de droit international privé states:

L'application d’une disposition du droit désigné en vertu de l'alinéa 1er est écartée si cette disposition prohibe le mariage de personnes de même sexe, lorsque l'une d'elles a la nationalité d'un Etat ou a sa résidence habituelle sur le territoire d'un Etat dont le droit permet un tel mariage. ${ }^{100}$

This rule is a codification of the Belgian public policy exception. ${ }^{101}$ Belgian law is thus applied if a spouse has the nationality of or is habitually resident in a jurisdiction where same-sex marriage is permitted. Furthermore, it is suggested that for the purpose of the application of article 46(2) Code de droit international prive, ${ }^{102}$ any legally recognized samesex relationship is sufficient, even a registered partnership. ${ }^{103}$ However, the rule has been criticized for applying Belgian law to a relationship between two people who bear no connection to Belgium, thereby stretching the limits of the public policy exception. ${ }^{104}$ Despite this criticism, Bailey identified the rule as a possible model for Canada. ${ }^{105}$ In other European countries — namely Sweden, the Netherlands, and Spain — one of the spouses must be habitually resident in that jurisdiction or have its nationality. ${ }^{106}$ Even if one disregards the fact that the Belgian rule applies Belgian law where there is no territorial connection with Belgium, it still differs from the proposed Canadian rule. It requires that the marriage of a same-sex couple could be recognized in at least one jurisdiction with which at least one spouse has more than a temporary connection. It stands to reason that by virtue of this, both the same-sex marriage and divorce at least have a chance of creating some legal effect. The

100 Code de droit international privé (Bel), Moniteur Belge 2004, no 269 [Code DIP (Bel)].

101 See Jean-Yves Carlier, “Article 46: Formation du mariage” in Het Wetboek internationaal privaatrecht becommentarieerd = Le Code de droit international privé commenté ed by Johan Erauw, et al (Brussels: Intersentia, Bruylant, 2006) 246 at 251-52.

102 Code DIP (Bel), supra note 100.

103 Carlier, supra note 101 at 251-52.

104 "[L]a Belgique ne pourrait plus accepter de reconnaître dans son ordre juridique un choix différent effectué par un législateur étranger, parce que les effets qui en résulteraient pour les citoyens étrangers résidant en Belgique seraient devenus contraires aux exigences de l'ordre public international belge?” Jean-Louis Renchon, “L’avènement du mariage homosexuel dans le Code civil belge” (2004) 81 Rev b dr int dr comp 179 at 189; Wautelet, supra note 43 at 147 calls it a "rather radical option." See also for further references $I d$, "Les couples de personnes de même sexe en droit belge, sous l'angle particulier du droit international privé” in Rapports belges au Congrès de l'Académie internationale de droit comparé à Utrecht, ed by Eric Dirix \& Leleu Yeves-Henri (Brussels: Bruylant, 2006) 307 at 314. 
marriage or divorce of a same-sex couple married in Canada who are both resident in jurisdictions where same-sex marriage is not recognized will not have any legal effect. Giving effect to it in Canada creates a limping relationship. Given the problem of limping relationships and the role of comity in private international law, it would be a wise policy choice to also require minimum contact with Canada for a statutory public policy exception.

\section{NO CONSTITUTIONAL IMPEDIMENT TO AN EXTRATERRITORIAL Application of Canadian MarRiage Laws}

Despite criticism of the new section 7 of the $C M A$, it should be noted that from a constitutional point of view, there is no impediment to the de facto application of Canadian law instead of the foreign law by virtue of section 7 of the CMA. This would not necessarily be the same if such a rule were enacted by a provincial legislature. Provincial Canadian private international law is influenced by the fact that each province and territory is its own jurisdiction with its own set of laws. Consequently, by virtue of the vertical separation of powers in the Constitution Act, $1867,{ }^{107}$ a province can only render its own law applicable if there is sufficient connection with the jurisdiction. ${ }^{108}$ Achieving this goal is one of the purposes of the provincial private international law systems. ${ }^{109}$ Furthermore, provincial private international law does not differentiate between interprovincial conflicts and truly international conflicts, instead using the same connecting factors for both. Thus, the sufficient connection restriction limits the province's ability to render their domestic laws internationally applicable without sufficient connection to the province. But, as acknowledged by the Supreme Court of Canada, Parliament is not bound by the same constraints: "This could, no doubt, be defended on the basis of sovereignty. Indeed the federal Parliament is expressly permitted by our Constitution to legislate with internationally extraterritorial effect. But this appeal is concerned with the provinces within Confederation."

\section{Alternative Proposal}

Partly, the problem with "foreign" same-sex couples is a result of the determination of the "foreign" element. As discussed above, the common law provinces use domicile as a connecting factor. The domicile concept is problematic because it is not easy to change one's domicile. Thus, it is possible that there are couples who are resident in Canada, but not domiciled here. While these couples might be able to raise the public policy exception, legal security for these couples - who have a very real interest in having their marriage recognized in Canada - might better be achieved by a completely new rule that replaces the domicile rule. Apart from the problems with the concept of domicile already mentioned above, domicile is an anachronistic concept. It was applied by British courts at the time of the British Empire, where British citizens had to live in the colonies for extended periods of

(UK), 30 \& 31 Vict, c 3, reprinted in RSC 1985, App II, No 5.

Although mostly dealing with jurisdiction of courts, see the following passage: "The private international law rule requiring substantial connection with the jurisdiction where the action took place is supported by the constitutional restriction of legislative power 'in the province'” (Morguard Investments Ltd v De Savoye, [1990] 3 SCR 1077 at 1109).

See Emanuelli, supra note 40 at para 92.

Hunt $v$ T\&N plc, [1993] 4 SCR 289 at 328. 
time without feeling any attachment to their actual place of residence. ${ }^{111}$ As the UK was always a state comprised of different jurisdictions, the concept of domicile had to be developed as a feasible alternative connecting factor to nationality.

\section{A. ApPlying the LeX Loci Celebrationi}

Castel, Castel, and Cossman have a different suggestion: replacing the lex domicili with a lex loci celebrationi rule to determine formal and essential validity of all marriages. ${ }^{112} \mathrm{I}$ disagree with that proposal. Most other jurisdictions worldwide use a long-term connecting factor, for example, nationality or domicile — both of which are often the same - or habitual residence to determine essential validity. Using a radically different approach which makes the very short-lived place of marriage determinative for essential validity only furthers disparity and thus limping relationships. Furthermore, as Castel and Castel themselves point out, ${ }^{113}$ wedding tourism is a widespread phenomenon. Many Canadian couples, regardless of whether they are of the same sex or of different sexes, might be surprised to find out that they will suddenly have to conform to the essential-validity requirements of the jurisdiction in which their wedding takes place rather than the requirements of their Canadian home jurisdiction.

Cossman relies heavily on the Convention On Celebration And Recognition of the Validity of Marriages. ${ }^{114}$ She argues that "[t]he Convention would make the law of the place of celebration the determinant of the validity of a marriage."115 Her argument is based on a reading of two articles of the Hague Marriages Convention. ${ }^{116}$ By making this argument, Cossman not only uses a rule about the formal validity of a marriage that is already identical to the current rule in Canada to argue for a change, she also conveniently ignores article 3 Hague Marriages Convention, which provides that the law of the place of celebration is only relevant if at least one of the spouses is a national of, or habitually resident, in that state. ${ }^{117}$ In other words, the Hague Marriages Convention uses nationality and habitual residence as the primary connecting factors and place of celebration only as a secondary connecting factor in case the law of one of these connecting factors were to deny the capacity to marry, but the other does not.

\footnotetext{
$111 \quad$ Walker, supra note 30, ch 4 at 17.

$112 \quad$ Castel \& Castel, supra note 4 at 307; Cossman, supra note 5 at 17.

113 Castel \& Castel, ibid.

114 Hague Conference on Private International Law, Convention on Celebration and Recognition of the Validity of Marriages, online: <http://www.hcch.net/upload/conventions/txt26en.pdf> [Hague Marriages Convention].

115 Cossman, supra note 5 at 17.

116 "The formal requirements for marriages shall be governed by the law of the State of celebration" (Hague Marriages Convention, supra note 114, art 2); "A marriage validly entered into under the law of the State of celebration or which subsequently becomes valid under that law shall be considered as such in all Contracting States, subject to the provisions of this Chapter” (ibid, art 9).

117 See also Christian von Bar, “Die eherechtlichen Konventionen der Haager Konferenz(en)”(1993) 57:1-2
} RabelsZ 63 at 87-89. 


\section{B. REPLACING DOMICILE WITH HABITUAL RESIDENCE}

\section{The Habitual Residence CONCEPT}

Given what has been said in the preceding subsection, if anything, the Hague Marriages Convention stands for the proposition that habitual residence is the possible alternative to domicile in modern private international law. The modern concept of "habitual residence" puts less emphasis on the onerous element of intent. ${ }^{118}$ The rigidity of the common law domicile concept was recognized by the Australian High Court, which reiterated a statement by Eugene Scoles et al that modern private international law legislation uses the concept of "habitual residence" rather than "domcile" "[t] o avoid the distasteful problems of the English concept [of domicile] and the uncertainties of meaning and proof of subjective intent."119

Habitual residence is often referred to as a question of objective fact, not subjective intent. ${ }^{120}$ This view is not unreservedly shared in England, where Lord Scarman, with approval of the other Lords, described residence as follows: "I unhesitatingly subscribe to the view that 'ordinarily resident' refers to a man's abode in a particular place or country which he has adopted voluntarily and for settled purposes as part of the regular order of his life for the time being, whether of short or of long duration." ${ }^{121}$ In the same case, Lord Scarman wrote:

There are two, and no more than two, respects in which the mind of the "propositus" is important in determining ordinary residence. The residence must be voluntarily adopted. Enforced presence by reason of kidnapping or imprisonment, or a Robinson Crusoe existence on a desert island with no opportunity of escape, may be so overwhelming a factor as to negative the will to be where one is. And there must be a degree of settled purpose. The purpose may be one; or there may be several. It may be specific or general. All that the law requires is that there is a settled purpose. ${ }^{122}$

Scottish courts, on the other hand, apply a purely factual analysis as well. ${ }^{123} \mathrm{New}$ Zealand and Australian courts see settled purpose as one of many elements of a broad analysis into the question of residence, while no single element is a necessary condition. ${ }^{124}$ This latter approach seems to be most consistent with the flexible and broad inquiry that is meant to be achieved by using habitual residence as a connecting factor.

There is some authority in Canada that restricts the flexibility of the habitual — or ordinary - residence test. "In my opinion, the arrival of a person in a new locality with the intention of making a home in that locality for an indefinite period makes that person

Re Walker and Walker (1970), 14 DLR (3d) 155 (Ont (H Ct J)) [Re Walker] at 158; Walker, supra note 30, ch 4 at 17.

119

120

Eugene F Scoles et al, Conflict of Laws, 4th ed (St Paul: Thomson West, 2004) at 247; quoted in $L K v$ Director-General, Department of Community Services, [2009] HCA 9, 237 CLR 582 [LK] at para 24. Baumfelder v Secretary of State of Canada, [1927] Ex CR 86 at 91; Re Walker, supra note 118 at 158, Pennel J; Lor v Lor (1978), 25 NSR (2d) 243 (SC (AD)).

$R v$ Barnet London Borough Council, [1983] 2 AC 309, (HL (Eng)) at 343.

Ibid at 344.

"On or our part, with great respect, we are not satisfied that in all cases the residence must be voluntarily adopted before there can be habitual residence. Even though Robinson Crusoe had no opportunity to escape, we are inclined to think that he had his habitual residence on the desert island" (Cameron $v$ Cameron (1995), [1996] SC 17 (Ct Sess) at 20).

Punter v Secretary for Justice, [2007] 1 NZLR 40 (CA); LK, supra note 119 at para 45. 
ordinarily resident in that community." ${ }^{25}$ The problem of such a definition is that it does not significantly differ from the domicile concept. On the other hand, in Jenkins v. Jenkins, ${ }^{126}$ Justice Perkins cites with approval the following passage from Macrae v. Macrae: ${ }^{127}$

Ordinary residence can be changed in a day. A man is ordinarily resident in one place up till a particular day: he then cuts the connexion he has with that place — in this case he left his wife; in another case he might have disposed of his house or anyhow left it and made arrangements to make his home somewhere else. Where there are indications that the place to which he moves is the place which he intends to make his home for at any rate an indefinite period, then as from that date in my opinion he is ordinarily resident at the place to which he has gone. ${ }^{128}$

\section{The CASE FOR HABITUAl Residence}

Using habitual residence in lieu of domicile as the connecting factor has several advantages. First, if a couple is habitually resident in Canada, there is sufficient connection to the Canadian territory that warrants the application of Canadian law. While the public policy exception is no longer needed, such a connection would have been sufficient to raise it in the first place. Second, the application of the law of the spouses' habitual residence better meets those parties' expectations, who might not be aware that they have not yet passed the change of domicile test. Third, since the spouses are resident in Canadian territory, their same-sex marriage is guaranteed to have the legal effects that the parties intended to achieve. Rather than trying to lure foreign same-sex couples to Canada for the wedding ceremony with the false promise of a "legal" marriage that does not in fact have any legal effect for the spouses, it is guaranteed that a Canadian same-sex marriage is legally binding. Furthermore, in principle, there is no reason why the habitual residence rule should not be extended to spouses of opposing sexes as well. The equality of same-sex couples could thus be legislatively recognized by the fact that the private international law regime does not distinguish between same-sex and heterosexual marriages.

\section{Constitutional Power for Change}

Parliament has the power to make the proposed change. While legislative power over the private law incidents of marriage rests with the provinces, ${ }^{129}$ Parliament has jurisdiction over the status question. Any federal legislative decision on whom to award marital status to is not ultra vires merely because Parliament, at the same time, also decides who will benefit from the incidental rights. This is because the answer to the question of whether someone receives marital status necessarily answers the question of who receives the incidental rights of marriage. ${ }^{130}$ In effect, provincial power to legislate over incidental rights is a power to legislate which incidental rights married spouses have, not whether they have them.

\footnotetext{
$125 \quad$ MacPherson v MacPherson (1976), 13 OR (2d) 233 (CA) at 239.

126 (2000), 8 RFL (5th) 96 (Ont Sup Ct J) [Jenkins].

127 [1949] P 397 (CA Civ).

128 Ibid at 403 [emphasis added]; referred to and quoted almost perfectly in Jenkins, supra note 126 at para 13.

129 Reference re Same-Sex Marriage, 2004 SCC 79, [2004] 3 SCR 698 at para 32. Ibid.
} 
The provincial power to legislate in private international law matters, as far as the matter at hand is concerned, is a function of its power to legislate in matters of "civil rights" (section 92(13) of the Constitution Act, 1867). On the other hand, if a subject matter is within the power of Parliament, that subject matter includes private international law questions. ${ }^{131}$

This article does not argue that current provincial rules on the law applicable to the essential validity of marriage — in particular article 3083 CCQ — are ultra vires because the subject matter falls under federal jurisdiction. Rather I am arguing that because federal law currently does not contain a rule on the law applicable on essential validity, but because this question is incidental to the question to which incidents married spouses are entitled, the provinces had to fill the legislative gap. However, once Parliament enacts a rule determining the law applicable on essential validity of marriage, the provincial rules become ineffective. ${ }^{132}$

While a rule determining that the married status of a person is to be judged by their habitual residence rather than their domicile would be within the powers of Parliament, this does not resolve the matter entirely. Rather, a comprehensive approach to international samesex marriage requires a coordinated federal-provincial effort. Apart from the law applicable to the essential validity of the marriage, the law applicable on the incidents of marriage needs to be determined.

Private law incidents of marriage are a provincial matter, and therefore private international law on the incidents of marriage is provincial as well. Obviously, it would be problematic if marital status is governed by a law determined by habitual residence, while marital incidents are governed by a law determined by another connecting factor. In fact, the common law rule is to apply the law of domicile to the incidents of marriage.

While it is true that once the validity of the marriage is determined, in this case by federal law of capacity, the paramountcy doctrine requires that provincial law accepts the marriage as valid. However, this does not yet settle the question of which law governs these incidental effects and how provincial law settles the conflict-of-laws question. If two different laws apply to one legal situation, the term "dépeçage" is used. ${ }^{133}$ A dépeçage may occur in international same-sex marriages because the connecting factors used to determine status, personal rights, and matrimonial property diverge.

For instance, the Canadian provinces have different private international law regimes regarding matrimonial property. Absent a choice-of-law provision in a domestic contract, British Columbia and Saskatchewan follow a matrimonial domicile rule; Alberta, Manitoba, and New Brunswick apply the lex fori where habitual residence is a requirement for jurisdiction; Newfoundland and Labrador, Nova Scotia, Ontario, Prince Edward Island, and

131 See Tropwood AG v Sivaco Wire \& Nail Co, [1979] 2 SCR 157 at 166-67; see also Emanuelli, supra note 40 at para 91 .

132 See WR Lederman, “The Concurrent Operation of Federal and Provincial Laws in Canada” (1963) 9:3 McGill LJ 185.

133 Regarding the problem of dépeçage, see generally Emanuelli, supra note 40 at para 400; Paul Lagarde, “Le dépeçage dans le droit international privé des contrats” (1975) 11 Riv dir int priv proc; Willis LM Reese, "Dépeçage: A Common Phenomenon in Choice of Law” (1973) 73:1 Colum L Rev 58. See for Canadian common law jurisdictions regarding contracts Walker, supra note 30, ch 31 at 51. 
the Yukon apply the law of the last common habitual residence, subsidiarily the lex fori; ${ }^{134}$ and Quebec uses "Kegel's ladder," 135 a set of connecting factors (the primary connecting factor is a valid choice-of-law provision in a domestic contract; failing that domicile at the time of their marriage; or if they have different domiciles, the law of their first common residence; or, failing that, the law of their common nationality; or, failing that, the law of the place of solemnization of their marriage or civil union). ${ }^{136}$ The conflict-of-laws rules on incidental effects and essential validity should be harmonized.

\section{CONCLUSION}

This analysis has shown that the impossibility of the application for divorce by foreign-domiciled same-sex spouses whose home jurisdiction does not recognize same-sex marriages before the passage of Bill C-32 was not due to a mere "legislative gap"137 for which political blame can be attributed. Rather, it was a function of (1) the methodology of conflict of laws in general; and (2) the use of domicile as a connecting factor when determining the essential validity of marriage in particular. Furthermore, before the passage of Bill C-32, as far as couples who would move their residence to Canada were concerned, the public policy exception was sufficient to enable Canadian courts to disregard the foreign law not recognizing same-sex marriages.

However, as far as couples who come from jurisdictions where same-sex marriages are not recognized and who have no real and substantial connection to Canada are concerned, the pretence that these couples are able to enter a legally recognized marriage in Canada is overly optimistic at best, and a cynical furthering of wedding tourism at worst. In fact, these couples' marriage will still not be recognized anywhere outside Canada, and since they have no real and substantial connection to Canada, the recognition of the marriage in Canada is of no benefit to them. By indiscriminately changing the CMA to encompass both those couples who have a real and substantial connection to Canada that falls short of domicile and those who have no such connection, Parliament has enacted a bad law, perpetuating a fiction. A better approach would have been to address the real problem: the use of the outdated domicile concept in international family law.

Halsbury's Laws of Canada (Markham: LexisNexis Canada, 2011) “Conflicts of Laws” at para HCF177.

Christian von Bar, "Personal Effects of Marriage" in René David \& Ulrich Drobnig, eds, Private International Law, International Encyclopedia of Comparative Law, vol 3 (Tübingen: Mohr Siebeck, 1986) at para $17, \mathrm{n} 82$.

CCQ, supra note 38, art 3123.

As put by the Minister of Justice (as he then was), Bob Nicholson (Payton, supra note 23). 